Jurnal Keperawatan Silampari

Volume 1, Nomor 2, Juni 2018

e-ISSN : 2581-1975

p-ISSN : 2597-7482

Doi: https://doi.org/10.31539/jks.v1i2.22

\title{
PENGARUH TEKNIK PERNAPASAN BUTEYKO TERHADAP ACT (ASTHMA CONTROL TEST)
}

\author{
Marlin Sutrisna $^{1}$, Emmy H Pranggono ${ }^{2}$, Titis Kurniawan ${ }^{3}$ \\ Program Magister Ilmu Keperawatan, Universitas Padjadjaran ${ }^{1}$ \\ Program Studi Ilmu Keperawatan, Universitas Padjadjaran ${ }^{2,3}$ \\ marlinsutrisna@yahoo.co.id ${ }^{1}$
}

\begin{abstract}
ABSTRAK
Penelitian ini bertujuan untuk mengetahui pengaruh teknik pernapasan buteyko terhadap ACT (asthma control test). Jenis penelitian quasi eksperimental dengan pendekatan pretest and post test one group design ini melibatkan 14 pasien asma yang dipilih dari Poli Paru RSUP Dr. Hasan Sadikin Bandung dengan consecutive sampling. Kontrol asma dikumpulkan dengan menggunakan ACT secara time series. Data yang terkumpul dianalisis secara deskriptif dan inferensial dengan skala signifikansi $\mathrm{p}<0,05$. Hasil penelitian menunjukkan adanya perbedaan rerata yang signifikan lebih tinggi antara skor ACT setelah diberikan teknik pernapasan buteyko $(19,79 \pm 1,47)$ dengan skor ACT pada minggu III $(17,50 \pm 1,78)$, minggu II $(12,64 \pm 1,82)$, minggu I $(9,57 \pm 1,95)$, dan pretest $(7,64 \pm 1,82)$. Post hoc analisis menemukan skor post test minggu ke empat $(19,79 \pm 1,47)$ signifikan lebih baik dari pada post test minggu III $(17,50 \pm 1,78)$, minggu II $(12,64 \pm 1,82)$, minggu I $(9,57 \pm 1,95)$, dan pre-test $(7,64 \pm 1,82)$ dalam meningkatkan kontrol asma. Simpulan, ada pengaruh teknik pernapasan buteyko terhadap ACT (asthma control test).
\end{abstract}

Kata Kunci: ACT, Asma Bonkial, Buteyko, Teknik Pernapasan

\begin{abstract}
This study aims to determine the effect of buteyko breathing technique on asthma control test (ACT).The quasi experimental study with the pretest and post test one group design approach involved 14 patients with asthma selected from the Lung Polyclinic of Dr. Hasan Sadikin Bandung with consecutive sampling. Asthma control was collected using time series ACT. The collected data were analyzed descriptively and inferentially with the scale of significance $p<0.05$.The results showed a significantly higher mean difference between ACT scores after buteyko breathing technique $(19.79 \pm 1.47)$ with ACT score at week III (17.50 \pm 1.78$)$, week II (12.64 \pm 1.82$)$, week I (9.57 \pm 1.95$)$, and pretest $(7.64 \pm 1.82)$. Post hoc analysis found the fourth week post test score (19.79 \pm 1.47) significantly better than post test week III (17.50 \pm 1.78$)$, week II (12.64 \pm 1.82$)$, week I (9.57 \pm 1.95$)$, and pretest (7.64 \pm 1.82$)$ in improving asthma control. Conclusion, there was an effect of buteyko breathing technique on asthma control test $(A C T)$.
\end{abstract}

Keywords: ACT, Breathing Technique, Bronchial Asthma, Buteyko 


\section{PENDAHULUAN}

Kontrol asma bronchial yang buruk merupakan masalah kesehatan yang serius. Asma bronkial terus menjadi masalah kesehatan masyarakat utama di dunia (To et al, 2013). Di seluruh belahan dunia, prevalensi asma diperkirakan mencapai 334 juta orang dari segala usia (Global Asthma Network, 2014). Pada tahun 2025 diperkirakan prevalensi asma di dunia mengalami peningkatan mencapai 400 juta orang (Masoli, Fabian, Holt, \& Beasley, 2004).

Prevalensi penyakit asma terus meningkat di negara-negara maju. Penyakit ini telah mengalami peningkatan yang drastic dalam 2-3 dekade terakhir. Pada negaranegara berkembang, kejadian asma banyak ditemui karena faktor ekonomi (Eder, Ege, \& Von Mutius, 2006). Prevalensi asma pada tahun 2002-2003 banyak ditemui pada usia antara 18-48 tahun (Global Asthma Network, 2014). Sedangkan menurut Riset Kesehatan Dasar Tahun 2013 penyakit asma di Indonesia menempati urutan tertinggi untuk kategori penyakit tidak menular sebesar 4,5\% dan lebih banyak dialami perempuan (Penelitian \& Pengembangan, 2013).

Dampak negatif dari kontrol asma buruk dapat mengganggu pola tidur, aktivitas sehari-sehari, kerusakan paru, dan berbagai komplikasi asma lainnya (Li et al, 2005). Asma menyebabkan kecemasan dan depresi. Kecemasan tersebut muncul karena konsumsi kortikosteroid dan meningkatnya jumlah hari rawat inap di rumah sakit. Dampak kecemasan dan depresi salah satunya adalah penurunan kualitas hidup (Kullowatz, Kanniess, Dahme, Magnussen, \& Ritz, 2007). Selain memberikan dampak fisik, psikologis, ataupun fungsional, asma juga berpengaruh terhadap kualitas hidup penderitanya bahkan meningkatkan angka morbiditas (To et al, 2013).

Penyakit asma berdampak pada finansial karena perawatan asma membutuhkan biaya yang besar untuk biaya medis seperti rawat inap dan obat-obatan. Asma juga dapa tmenyebabkan kematian dini (Masoli et al, 2004). Peningkatan pengeluaran biaya pengobatan disebabkan oleh control penyakit yang ketat. Kehilangan hari kerja terjadi pada pasien asma karena kekambuhan asma (Dal Negro et al, 2007).

Penatalaksanaan asma dilakukan dengan tujuan untuk mengelola asma jangka panjang dan eksaserbasi asma melalui empat komponen penting meliputi penilaian atau pemantauan, pendidikan kesehatan, mengontrol faktor yang berkontribusi terhadap tingkat keparahan asma untuk mencegah timbulnya kekambuhan gejala asma yang dilakukan secara mandiri oleh pasien, dan pengobatan farmakologis (Prevention, 2007). Untuk mencapai tujuan tersebut Center Of Disease Control and Prevention (CDC) melakukan dengan cara edukasi, perubahan perilaku, menghindari factor pencetus, regimen pengobatan, dan follow up medis yang teratur. Oleh karena itu, program yang terintegrasidan dapat memfasilitasi semua upaya penalataksanaan asma tersebut sangat diperlukan oleh pasien asma, sehingga outcome asma menjadi lebih baik (Williams, Schmidt, Redd \& Storms, 2003).

Menurut Bateman et al, (2008) penatalaksanaan asma bertujuan untuk mencapai dan mempertahankan control asma dengan pendekatan manajemen asma yang baik seperti kerjasama antara pemberi pelayanan kesehatan dengan pasien, manajemen diri, dan menetapkan tujuan dalam pengobatan. Tetapi penatalaksanaan asma bronkial yang saat ini digunakan dengan terapi farmakologi untuk membantu mengurangi atau meredakan serangan asma bronchial seperti bronkodilator dan kortikosteroid. Kombinasi kedua obat tersebut (Long acting $\beta 2$ agonist+inhaled kortikosteroid) terbukti efektif karena kedua obat ini dapat menaikan regulasi $\$ 2$ adrenergik. Selain itu 
kombinasi ICS/long acting $\beta 2$ agonis lebih banyak disukai orang dewasa (Fm, M, Greenstone, \& $\mathrm{Tj}, 2010)$.

Kelemahan dari penggunaan terapi farmakologi jangka panjang yaitu memiliki efek samping terutama jika tidak melakukan kontrol pengobatan. Penggunaan antileukotrien ataupun kortikosteroid inhalasi beresiko memiliki efek samping penekanan pertumbuhan pada anak-anak, peningkatan enzim hati, sakit kepala, mual, supresi adrenal, osteopenia, dan kematian (Ducharme, Chauhan, 2014). Menurut Thomas (2004) penggunaan obatan-obatan jangka panjang memiliki masalah finansial atau pengeluaran biaya yang cukup mahal. Penggunaan obat-obatan asma seperti bronkodilator yang terlalu sering (ketergantungan) dapat menjadi kontra produktif dan berkontribusi untuk meningkatan kematian.

Komplikasi dari pengobatan asma dapat dicegah dengan memberikan pembaharuan terapi yaitu dengan diberikan terapi pendamping (terapi non medis). Terapi non medis bertujuan mencapai gaya hidup yang normal, menghindari serangan, dan mengembalikan fungsi paru yang optimal (Bruurs, Van Der Giessen \& Moed, 2013). Terapi non farmakologi yang diberikan sebagai terapi pendamping farmakologi adalah teknik pernapasan buteyko. Menurut Cooper et al, (2003) teknik pernapasan buteyko merupakan teknik olah napas yang dikembangkan khusus untuk pasien asma bronkial.

Kelebihan dari teknik pernapasan buteyko dapat menurunkan frekuensi serangan asma (kekambuhan), mencegah tingkat keparahan, dan menurunkan dosis kortikorsteroid inhalasi serta memperbaiki PEFR. Selain itu teknik pernapasan buteyko dapat menghentikan batuk, hidung tersumbat, sesak napas, wheezing, dan memperbaiki kualitas hidup. Teknik pernapasan buteyko tidak memiliki efek samping (Hassan, Riad \& Ahmed, 2012).

Penelitian yang dilakukan oleh Prem, Sahoo \& Adhikari (2013) bahwa kelompok yang diberikan teknik pernapasan buteyko menunjukan peningkatan kualitas hidup dengan 4 subdomain yaitu gejala, aktivitas, emosi, lingkungan dan control terhadap serangan asma. Menurut Cowie, Conley, Underwood \& Reader (2008) terapi teknik pernapasan buteyko dapat meningkatkan control asma, mengurangi penggunaan terapi kortikosteroid inhalasi. Tidak ada efek samping yang dilaporkan dalam kelompok yang diberikan intervensi teknik pernapasan buteyko. Berdasarkan latar belakang diatas, penting untuk dilakukan penelitian tentang pengaruh teknik pernapasan buteyko terhadap ACT (asthma control test). Sedangkan tujuan penelitian untuk mengetahui pengaruh teknik pernapasan buteyko terhadap ACT (asthma control test).

\section{METODE PENELITIAN}

Penelitian quasi eksperimental dengan pendekatan pretest and post test one group design yang terdiri dari 14 pasien asma dengan consecutive sampling. Penelitian dilakukan di Poli Paru Rumah Sakit Hasan Sadikin Bandungdari tanggal 20 Juni sampai 24 Juli 2017. Instrumen ACT (Asthma Control Test) di lakukan secara time series artinya diukur pada saat pretest, minggu pertama, kedua, ketiga, dan keempat. Data yang terkumpul dianalisis secara deskriptif dan inferensial yaitu dengan menggunakan uji repeated ANOVA dan dilanjutkan dengan analisis uji Post Hoc dengan skala signifikansi $\mathrm{p}<0,05$. 


\section{HASIL PENELITIAN}

Penelitian dengan desain time-series ini memberikan intervensi sebanyak minimal dua kali dalam seminggu selama empat minggu. Pemeriksaan ACT dilakukan sebanyak lima kali yaitu, pretest (awal) kemudian dilanjutkan pemeriksaan pada minggu I, minggu II, Minggu III, dan post test pada minggu ke IV. Berikut akan disajikan hasil analisis univariat karakteristik responden yaitu: usia responden, jenis kelamin, riwayat alergi dan riwayat keluarga yang mengalami asma (genetik). Distribusi karakteriktik responden penelitian disajikan pada tabel 1 dibawah ini :

Tabel. 1

Karakteriktik Responden ( $\mathrm{n}=14)$

\begin{tabular}{ccc}
\hline & F & $\%$ \\
\hline Jenis Kelamin & & \\
Laki-laki & 4 & 28,6 \\
Perempuan & 10 & 71,4 \\
Riwayat alergi & & \\
Ya & 9 & 64,3 \\
Tidak & 5 & 35,7 \\
Genetik & 12 & 85,7 \\
Ya & 2 & 14,3 \\
Tidak & Mean & SD \\
Usia (19-65 th) & 44 & 14,242 \\
\hline
\end{tabular}

Berdasarkan tabel 1 karakteristik responden secara umum dengan rerata usia 44 tahun, sebagian besar jenis kelamin responden yang mengalami asma perempuan $(71,4 \%)$ yang memiliki riwayat alergi $(64,3 \%)$ dengan riwayat genetik $(85,7 \%)$. Berikut ini disajikan hasil pengolahan data yang menggambarkan distribusi rerata skor ACT (Asma Control Test).

Tabel. 2

Distribusi rerata skor ACT $(\mathrm{n}=14)$

\begin{tabular}{crc}
\hline & Mean & Standar Deviasi \\
\hline Pre & 7,64 & 1,823 \\
P1 & 9,57 & 1,950 \\
P2 & 12,64 & 1,823 \\
P3 & 17,50 & 1,787 \\
P4 & 19,79 & 1,477 \\
\hline
\end{tabular}

Keterangan :

Pre : Sebelum/screening

P1 : Penggukuran Minggu Ke 1

P2 : Pengukuran Minggu Ke 2

P3 : Pengukuran Minggu Ke 3

P4 : Pengukuran Post Intervensi

Berdasarkan tabel 2 tampak bahwa rerata skor ACT mengalami peningkatan dari waktu ke waktu, dimulai dari pengukuran pretest dengan rerata 7,64 meningkat menjadi 19,79 pada minggu ke empat. Perbedaan tersebut dapat dilihat dari grafik di bawah ini : 


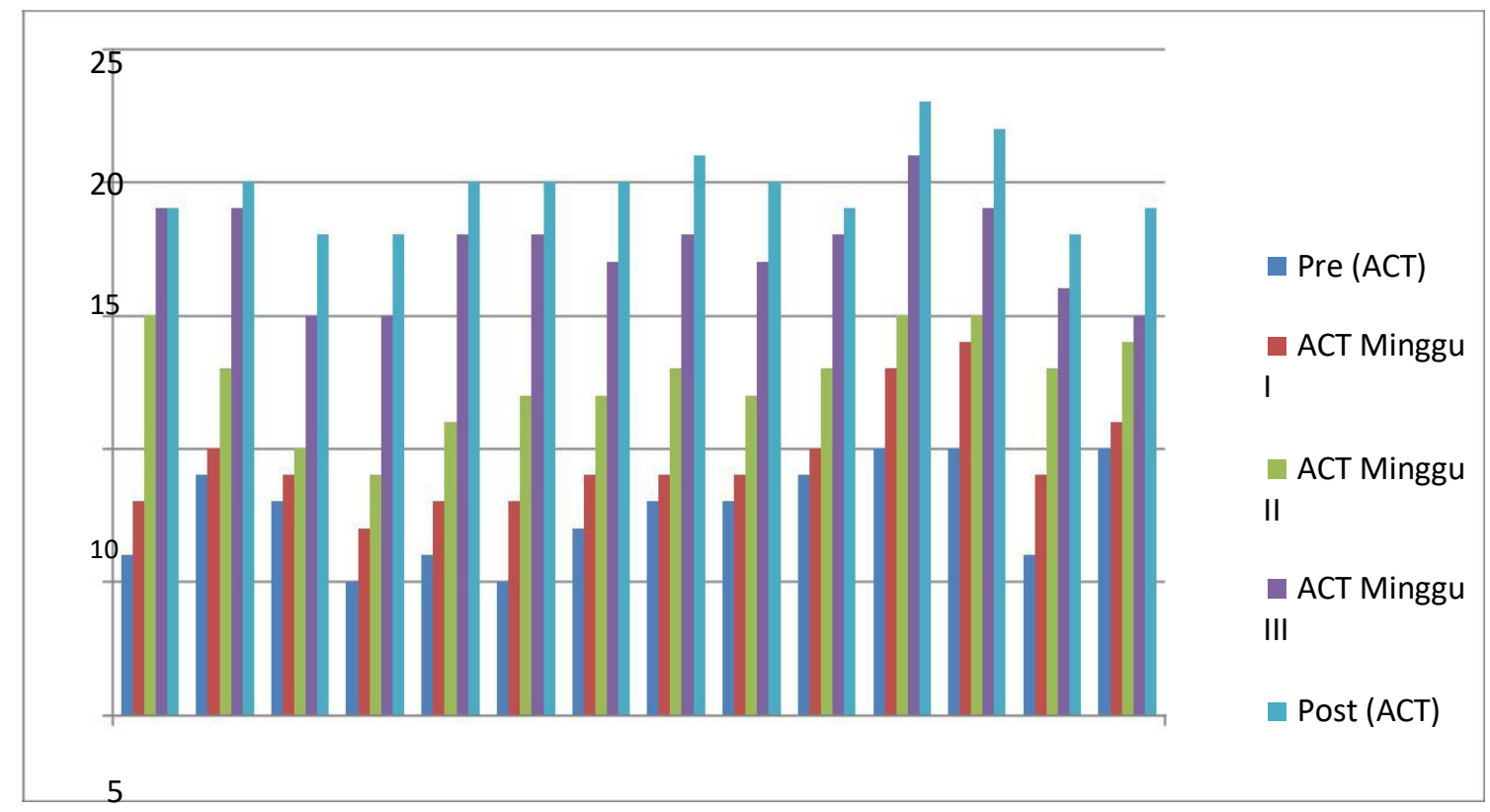

0

$\begin{array}{llllllllllllll}1 & 2 & 3 & 4 & 5 & 6 & 7 & 8 & 9 & 10 & 11 & 12 & 13 & 14\end{array}$

Grafik. 1

Asthma Control Test (ACT)

Berikut analisa data yang bertujuan mengetahui ACT (asthma control test) selama pretest, minggu pertama, minggu kedua, minggu ketiga, dan minggu keempat menggunakan uji repeated ANOVA dilanjutkan dengan melihat hasil Uji Post Hoc.

Tabel. 3

Hasil Analisis Uji Repeated ANOVA ( $\mathrm{n}=14)$

\begin{tabular}{ccc}
\hline & Mean \pm SD & $P$ \\
\hline Pre & $7,64 \pm 1,82$ & \\
P1 & $9,57 \pm 1,95$ & \\
P2 & $12,64 \pm 1,82$ & 0,000 \\
P3 & $17,50 \pm 1,78$ & \\
P4 & $19,79 \pm 1,47$ & \\
\hline
\end{tabular}

Tabel 3 diatas menunjukan hasil analisis uji repeated ANOVA pada responden yang diberikan teknik pernapasan buteyko. Tabel tersebut menjelaskan mengalami perubahan skor ACT. Hal ini dapat dilihat dari perubahan nilai rerata dan standar deviasi, dimulai dari pre intervensi sampai minggu ke empat setelah intervensi. Hasil uji statistik di peroleh nilai $p$ value $<0,05$, artinya terdapat perbedaan rerata ACT pada setiap pengukuran. Untuk melihat nilai perbedaan reratanya, maka dilakukan uji Post Hoc. 
Tabel. 4

Hasil Uji Post Hoc

\begin{tabular}{llllll}
\hline & Mean & $\begin{array}{l}\text { Perbedaan } \\
\text { Mean }\end{array}$ & CI $(95 \%)$ & \\
\hline Pre vs P1 & $(7,643-9,571)$ & 1,929 & $(-2,827)$ & $-(-1,030)$ & 0,000 \\
Pre vs P2 & $(7,643-12,643)$ & 5,000 & $(-6,541)$ & $-(-3,459)$ & 0,000 \\
Pre vs P3 & $(7,643-17.500)$ & 9,857 & $(-11.789)$ & $-(-7,925)$ & 0,000 \\
Pre vs P4 & $(7,6643-19,786)$ & 12,143 & $(-13,637)$ & $-(-10,649)$ & 0,000 \\
P1 vs P2 & $(9,571-12,643)$ & 3,0071 & $(-4.416)$ & $-(-1,727)$ & 0,000 \\
P1 vs P3 & $(9,571-17.500)$ & 7,929 & $(-9,677)$ & $-(-6,180)$ & 0,000 \\
P1 vs P4 & $(9,571-19,786)$ & 10,214 & $(-11,498)$ & $-(-8,931)$ & 0,000 \\
P2 vs P3 & $(12,643-17.500)$ & 4,857 & $(-6,220)$ & $-(-3,494)$ & 0,000 \\
P2 vs P4 & $(12,643-19,786)$ & 7,143 & $(-8,551)$ & $-(-5,735)$ & 0,000 \\
P3 vs P4 & $(17,500-19,786)$ & 2,286 & $(-3,249)$ & $-(-1,322)$ & 0,000 \\
\hline
\end{tabular}

Tabel 4 menunjukan hasil peningkatan skor ACT pada responden setiap minggu. Semua responden terjadi peningkatan rerata skor ACT yang signifikan setelah diberikan teknik pernapasan buteyko dalam setiap minggu $(p<0,05)$, artinya skor ACT pada minggu IV setelah diberikan teknik buteyko signifikan lebih tinggi daripada skor ACT pada minggu III, II, I, dan pretest.

\section{PEMBAHASAN}

Interpretasi hasil penelitian terhadap 14 responden yang diberikan teknik pernapasan buteyko di Poli Paru RSUP Hasan Sadikin Bandung, akan peneliti jelaskan pada bagian ini berdasarkan karakteristik responden dan tujuan penelitian. Selanjutnya peneliti menjelaskan keterbatasan dalam penelitian ini dan keunggulan intervensi.

Berdasarkan karakteristik responden dapat dijelaskan bahwa dari 14 responden sebagian besar responden berjenis kelamin perempuan $(71,4 \%)$. Faktor predisposisi perempuan yang mengalami asma lebih tinggi pada laki-laki mulai ketika masa puber, sehingga prevalensi asma pada anak yang semula laki-laki lebih tinggi dari pada perempuan mengalami perubahan dimana nilai prevalensi pada perempuan lebih tinggi dari pada laki-laki. Aspirin lebih sering menyebabkan asma pada perempuan (GINA, 2006).

Pada penelitian ini diketahui bahwa umur responden dari usia 19 tahun sampai 65 tahun. Berdasarkan penelitian yang dilakukan oleh Weiner, Magadle, Waizman, Weiner, Rabner \& Zamir (1998) bahwa usia responden yang diteliti pada 15 responden dengan kriteria usia kurang dari 65 tahun, memiliki rata-rata usia 35 tahun yang mengalami asma bronkial. Penelitian yang dilakukan oleh Hsu, King, Kuo \& Chiang (2004) yang meneliti karakteristik pasien asma. Peneliti meneliti 5 kelompok usia, dimana terdapat usia terbanyak pada kelompok usia 15-24 tahun sebanyak 29\%, di ikuti kelompok usia 25-44 tahun sebanyak 21\%, kelompok usia 15-24 tahun 12\% dan usia 45-64 tahun 8\%.

Hasil penelitian ini tampak sebagian besar responden $(64,3 \%)$ memiliki riwayat alergi. Salah satu faktor yang dapat menyebabkan terjadinya kekambuhan asma, salah satunya alergi. Alergi merupakan reaksi tubuh yang berlebihan terhadap terhadap suatu zat. Alergen dapat masuk melalui udara yang dihirup, disuntikkan, dimakan, atau disentuh. Alergi menyebabkan iritasi dan pembengkakan di daerah tertentu pada tubuh seperti hidung, mata, paru-paru, dan kulit. Alergen seperti serbuk sari, bulu binatang, tungau, debu, dan jamur merupakan faktor pemicu terjadinya kekambuhan asma. Alergi dipastikan dengan melakukan pemeriksaan skin tes alergi (Tobergte, Curtis, 2013). 
Eksaserbasi asma dipicu oleh alergen dalam rumah terutama pada keluarga yang belum mendapatkan pendidikan kesehatan. Lingkungan rumah terkait erat dengan kesehatan penghuninya. Alergen dalam ruangan seperti debu rumah, tungau, kecoa berisiko mengembangkan asma. Kualitas perumahan yang buruk sangat terkait dengan kontrol asma yang buruk (Crocker et al, 2016).

Akibat adanya trigger asma terjadi reaksi hipersensitivitas tipe I, II, III, dan IV yang di ikuti dengan reaksi mediator, inflamasi, kerusakan jaringan, dan gejala klinik. Sebanyak 85\% pasien inflamasi dimulai oleh Ig E (asma alergi) dan sisanya oleh proses yang independen terhadap Ig E (asma non alergi). Pada atopi paparan awal terhadap antigen menimbulkan sensitisasi. Antigen-presenting cell (APC) seperti makrofag menelan antigen dan mempresentasikannya kepada sel $\mathrm{T}$ (Th0) yang kemudian mengalami diferensiasi menjadi Th1 dan Th2. Th2 mengeluarkan sitokin antara lain IL4 dan IL13 yang menyebabkan sel B memproduksi IgE yang spesifik untuk antigen tersebut (Dahlan, Amin \& Soeroto, 2012).

Pada respon dini akibat adanya paparan selanjutnya menimbulkan reaksi antigenantibodi pada permukaan sel mastosit, yang di ikuti aktivasi dari sel dan pelepasan berbagai mediator (histamin dan heparin) serta mediator lain (prostaglandin, leukotrin, faktor aktifasi trombosit-PAF dan bradikinin) yang mengakibatkan bronkokonstriksi dan peningkatan hiperesponsif bronkus. Pelepasan sitokin seperti IL3, IL4, IL5, dan IL6 mengaktifkan limfosit $\mathrm{T}$ dan $\mathrm{B}$, yang merangsang sel mastosit dan menarik eosinofil, sehingga meningkatkan proses inflamasi (Dahlan, Amin \& Soeroto, 2012).

Pada penelitian sebagian besar $(85,7 \%)$ memiliki riwayat genetik. Menurut Kim, Kwon, Kim, Song, Kim, Kwon et al, (2010) bahwa asma memiliki komponen genetik. Penelitian dilakukan pada 185 pasien asma atopik. Hasil penelitian menunjukkan bahwa interaksi gemetik antara CD86 dan CD40L signifikan mempengaruhi asma atopik.

Peradangan pada asma bronkial sebagian besar disebabkan oleh mekanisme immunoglobulin (Ig E). Faktor genetik memiliki pengaruh terhadap pengembangan asma yang disebabkan oleh keadaan alergi. Namun, faktor lingkungan juga memberikan pengaruh terhadap respon inflamasi yang menyebabkan serangan asma dimana terjadi bronkospasme, edema, peningkatan mukosa yang disekresikan oleh sel epitel. Inflamasi merupakan respon pertahanan tubuh terhadap invasi mikroorganisme dan melawan efek toksik eksternal. Inflamasi pada asma alergi ditandai dengan peningkatan Ig E (Barnes, Drazen, 2009).

Pada penelitian yang dilakukan oleh Purnomo (2008) bahwa dari 52 responden yang mengalami asma, terdapat $60 \%$ memiliki riwayat keluarga dengan asma (genetik). Responden yang memiliki riwayat keluarga dengan penyakit asma memiliki resiko 24 kali untuk mengalami asma dibandingkan dengan anak yang tidak memiliki riwayat keluarga mengalami asma bronkial.

ACT (asthma control test) berguna untuk mengukur kontrol asma baik terkontrol maupun tidak terkontrol (buruk). Menurut Black, Hawks (2014) bahwa kontrol asma yang buruk disebabkan oleh kesalahan dalam teknik penggunaan inhaler, kepatuhan (compliance), lingkungan (environment), dan pertimbangan diagnosis alternatif. Kunjungan ulang ke pelayanan kesehatan setiap 1-6 bulan disarankan untuk pengawasan. Indikator adanya satu atau lebih gejala dari kontrol yang buruk (misal, terbangun malam hari dengan dipsnea atau batuk, meningkatnya penggunaan agonis beta, inhalan kerja pendek, seringnya ke pelayanan kesehatan akibat serangan) mengindikasikan peningkatan terapi. Ketika asma dibawah kontrol, maka saluran bronkial menjadi lebih halus, tidak ada sumbatan, dan udara masuk keluar mengalir 
dengan mudah (American College of Chest Physicians, 2004). Responden dalam penelitian ini melakukan kontrol pengobatan secara teratur, namun terus menerus mengalami kekambuhan karena faktor lingkungan, seperti debu, alergi dingin, makanan, dan aktivitas kerja yang berat. Namun, terdapat 1 responden yang belum mengerti cara pemakaian obat inhaler ketika pulang ke rumah. Sementara responden setiap bulan melalukan kontrol pengobatan secara rutin.

Langkah lain dalam mengontrol asma adalah bekerja sama dengan pemberi pelayanan kesehatan untuk membentuk rencana tindakan pada pasien asma. Pasien asma harus memiliki buku harian asma, yang membantu mengingatkan kapan obat harus diambil. Pemberi pelayanan kesehatan harus mengajarkan bagaimana menggunakan peak flow meter, kunjungan ke pelayanan kesehatan akan membantu dalam mengontrol asma, dan buku harian asma pasien harus akurat, untuk membantu pemberi pelayanan kesehatan dalam mengkaji kesehatan pasien asma dalam memanajemen asma secara langsung (The American College of Chest Physicians, 2004).

Beratnya asma diklasifikasikan berdasarkan intensitas terapi yang diperlukan untuk mencapai kontrol. Asma ringan adalah asma yang dapat dikontrol dengan intensitas rendah terapi misalnya dosis ringan inhalasi steroid atau penghambat leukotriene. Asma berat adalah asma yang terkontrol dengan intensitas tinggi atau disebut juga dengan kontrol yang belum tercapai meskipun dengan pemberian terapi intensitas tinggi. Asma berdasarkan karakteristik kontrolnya yang dicapai dengan pemberian pengobatan, dan selanjutnya dilakukan penyesuaian obat. Asma yang tidak terkontrol (uncontrolled) maka berikan pengobatan yang lebih intensif, asma terkontrol sebagian (partly controlled), maka tingkatkan pengobatan dan evaluasi ulang setiap satu bulan, dan terkontrol (well controlled), maka teruskan pengobatan sampai 3 bulan, kemudian kurangi obat secara bertahap untuk mencapai dosis minimal dengan asma tetap terkontrol (Dahlan, Amir \& Soeroto, 2012).

Domain dalam asma kontrol test terdiri dari gangguang aktivitas, sesak napas, gangguan tidur, penggunaan obat-obatan, dan penilaian kontrol asma. Menurut penelitian yang dilakukan oleh Haselkom, Chen, Miller, Fish, Peters, Weiss \& Jones (2010) yang mengevaluasi hubungan antara asma yang tidak terkontrol dan keterbatasan aktivitas. Pasien yang berpartisipasi dalam evaluasi asma dan studi pengobatan asma disurvei mengenai jenis dan tingkat keterbatasan aktivitas dalam 4 kategori yaitu aktivitas di luar rumah, aktivitas fisik, aktivitas sehari-hari, dan pemicu lingkungan. Hasil penelitian terdapat hubungan yang signifikan antara asma yang tidak terkontrol dan pembatasan aktivitas. Dibandingkan dengan penderita asma terkontrol, penderita asma yang tidak terkontrol berisiko tinggi mengalami keterbatasan aktivitas di luar, aktivitas fisik, dan aktivitas sehari-hari. Untuk membantu pasien mencapai kesehatan optimal, manajemen asma harus mencakup penilaian rutin terhadap keterbatasan aktivitas dan perawatan terkoordinasi.

Sesak napas juga termasuk dalam domain ACT (asthma control test). Menurut Maslan, Mims (2014) bahwa asma termasuk dalam penyakit kronis yang mempengaruhi saluran udara dari paru-paru menyebabkan pembengkakan, sekresi lengket (lendir), bronkospasme sehingga menjadi sesak napas. Kekambuhan asma ditandai dengan batuk, wheezing, dan kesulitan bernapas (Nhs American Academy of Allergy Asthma and Immunology, 2014). Selanjutnya domain gangguan tidur akibat sesak napas, batuk, wheezing. Gangguan pola tidur merupakan dampak dari asma bahkan terjadinya komplikasi asma (Li et al, 2005). 
Berdasarkan hasil penelitian bahwa peneliti membuktikan teknik pernapasan buteyko berpotensi untuk memberikan pengaruh positif secara subjektif yang di ukur dengan ACT (asthma control test). Hasil penelitian menunjukkan bahwa terdapat perbedaan rerata skor ACT sebelum dan sesudah latihan teknik pernapasan buteyko selama 4 minggu. ACT menunjukkan kontrol asma yang baik atau buruk pada pasien. Hal ini dikarenakan teknik pernapasan buteyko merupakan teknik yang menggabungkan pernapasan hidung, diafragma, dan control pause.

Menurut Bruton, Lewith (2005) bahwa pernapasan hidung dapat menghangatkan, memfiltrasi, dan melembabkan udara yang masuk. Pernapasan hidung dapat menghasilkan kadar oksida nitrat (Villareal et al, 2014). Pasien asma dianjurkan untuk bernapas melalui hidung dan menutup mulut, karena alergen masuk melalui mulut dapat memicu terjadinya bronkospasme sehingga terjadi sesak napas. Respon alami ketika sesak napas adalah usaha bernapas lebih dalam melalui mulut, sehingga memungkinkan menghirup alergen lebih banyak dan memicu bronkospasme lebih lanjut.

Secara biokimia, teknik pernapasan buteyko menghasilkan oksida nitrat (NO) yang berfungsi sebagai bronkodilatasi, vasodilatasi, permeabilitas jaringan, sistem imun, transportasi oksigen, respon insulin, memori, dan mood. Oksida nitrat (NO) dihasilkan oleh sinus paranasal (Courtney, 2008). Pernapasan diafragma yang dilakukan dapat mengubah tekanan dalam toraks yang menghasilkan gerakan udara. Pada saat inspirasi, kubah diafragma mendatar dan sangkar rusuk terangkat. Kontraksi diafragma dan otot interkostal eksterna menarik rusuk ke atas dan ke depan sehingga meningkatkan diameter transversal dan anteroposterior. Seiring dengan peningkatan volume dada dan paru, tekanan alveolar menurun dan udara tertarik ke paru. Toraks yang tambah luas membuat tekanan intrapleural menjadi negatif yang akan memperluas paru (Black, Hawks, 2014).

Bagian lain dari pernapasan buteyko adalah control pause yang bermanfaat mengurangi hiperventilasi. Control pause dapat meningkatkan kesehatan. Pada saat melakukan control pause, hidung ditutup dengan jari di akhir exhalasi dan hitung BTH (breathing holding time) dalam beberapa detik. Pasien harus menutup hidung sampai ada keinginan untuk bernapas. Kemudian melakukan inspirasi dan ekspirasi seperti normal kembali. Ketika melakukan exhalasi, maka mulut harus dalam keadaan tertutup (Rakhimov, 2013). Metode buteyko mengembangkan kemampuan meningkatkan control pause. Praktisi buteyko secara konsisten melaporkan control pause yang lebih lama dihubungkan dengan penurunan gejala asma. Selain itu control pause berguna untuk meningkatkan $\mathrm{CO}_{2}$ pada pasien asma yang kehilangan $\mathrm{CO}_{2}$ akibat hiperventilasi yang terus menerus. Dengan melalukan control pause akan mengatur ulang ritme pernapasan yang abnormal atau mengatur ulang pusat pernapasan otak sehingga kurang sensitif terhadap $\mathrm{CO}_{2}$ (Courtney, 2008).

Menurut Black, Hawks (2014) bahwa toraks dan diafragma mengubah tekanan dalam toraks untuk menghasilkan gerakan udara. Gerakan udara bergantung pada perbedaan tekanan antara atmosfer dan udara paru, dengan aliran udara dari daerah dengan tekanan tinggi ke daerah dengan tekanan rendah. Pada waktu inspirasi, kubah diafragma mendatar dan sangkar rusuk terangkat. Seiring dengan peningkatan volume dada dan paru, tekanan alveolar menurun dan udara tertarik ke paru.

Penelitian ini di dukung oleh Hassan, Riad \& Ahmed (2012), didapatkan bahwa teknik pernapasan buteyko mencegah tingkat keparahan asma, meningkatkan perbaikan PEFR dan kontrol asma yang di ukur dengan asthma control questionare (ACQ). Menurut Cowie, Conley, Underwood \& Reader (2008) teknik pernapasan buteyko dapat 
mengurangi penggunaan terapi kortikosteroid inhalasi. Pada penelitian ini, teknik pernapasan buteyko diberikan secara berkelanjutan setiap dua kali dalam seminggu selama 4 minggu. Hal tersebut disesuaikan dengan alat ukur kontrol asma yang mengukur kontrol asma setelah 4 minggu. Teknik pernapasan ini dapat menurunkan gejala asma, dan penggunaan obat-obatan (Cooper et al, 2003). Hal ini didukung oleh Solomen dan Aaron (2016) latihan pernapasan meningkatkan volume paru, pertugaran gas, mengontrol sesak napas, dan membantu membersihkan sekresi.

Menurut Cooper et al (2003) teknik pernapasan buteyko merupakan teknik olah napas yang dikembangkan khusus untuk pasien asma bronkial. Pada pasien asma mengalami hiperventilasi sebagai kompensasi tubuh agar tidak kehilangan kadar karbondioksida yang akan berdampak pada gangguan $\mathrm{pH}$ dan berkurangnya kadar oksigen dalam jaringan. Dengan diberikan teknik pernapasan buteyko dapat meningkatkan jumlah oksigen. Menurut Courtney (2007) bahwa teknik pernapasan buteyko menggunakan kontrol napas dan latihan menahan napas untuk mengobati berbagai kondisi kesehatan yang berhubungan dengan hiperventilasi dan karbon dioksida rendah.

Pada penelitian ini tampak peningkatan nilai ACT (asthma control test) dimulai pada minggu ketiga sampai minggu ke empat selama melakukan teknik pernapasan buteyko. Hal ini bertolak belakang dengan penelitian yang dilakukan oleh dilakukan oleh Cooper et al, (2003) menggambarkan bahwa terjadi perbaikan gejala asma, pengurangan dosis beta agonis pada pasien asma setelah diberikan 6 bulan intervensi pernapasan buteyko. Namun sejalan dengan penelitian yang dilakukan oleh Villareal et al, (2014) dimana hasil penelitiannya menunjukkan perbaikan kualitas hidup pada minggu ke empat diberikan latihan pernapasan buteyko.

Faktor lain yang mempengaruhi peningakatan skor ACT (asthma control test) yaitu terapi farmakologi. Pasien asma yang kontrol secara rutin di Poli Paru RSHS mendapatkan terapi farmakologi seperti pemberian bronkodilator. Hal ini merupakan pengobatan utama dalam mengatasi serangan asma. Selain itu penggunaan dosis atau frekuensi konsumsi bronkodilator ataupun kortikosteroid termasuk dalam domain Asthma Control Test (ACT). Hal ini di dukung oleh Fm, M, Greenstone \& Tj, (2010) bahwa penatalaksanaan asma bronkial dengan pemberian terapi farmakologi, karena dapat membantu mengurangi atau meredakan serangan asma, seperti terapi bronkodilator dan kortikosteroid. Kombinasi kedua obat tersebut (Long acting $\beta 2$ agonist+inhaled kortikosteroid) terbukti efektif untuk menangani penyakit asma bronkial karena kedua obat ini dapat mengurangi eksaserbasi dan memperbaiki fungsi paru. Selain itu kombinasi ICS/long acting $\beta 2$ agonis lebih banyak disukai orang dewasa.

Menurut Higashi, Zhu, Stafford \& Alexander (2011) terjadi peningkatan penggunaan steroid inhalasi dan kombinasi steroid/long acting $\beta 2$-agonis digunakan bertepatan dengan penurunan morbiditas dan mortalitas asma. Selain itu menurut Bedouch, Marra, FitzGerald, Lynd \& Sadatsafavi, (2012) bahwa pemberian farmakologi seperti kombinasi terapi inhalasi kortikosteroid/long acting beta-agonist telah menjadi komponen penting dari biaya asma.

Teknik pernapasan buteyko dapat menurunkan penggunaan bronkodilator, dan steroid inhalasi. Hal ini sesuai dengan penelitian yang dilakukan oleh Mchugh et al (2003). Penggunaan bronkodilator merupakan domain dalam mengukur skor ACT (asthma control test). Pada hasil ACT (asthma control test) tampak responden yang 
mengalami perbaikan gejala di ikuti dengan pengurangan penggunaan bronkodilator dari 3 kali per hari menjadi 1-2 kali dalam satu bulan.

Domain dalam asma kontrol test terdiri dari gangguan aktivitas, sesak napas, gangguan tidur, penggunaan obat-obatan, dan penilaian kontrol asma. Menurut penelitian yang dilakukan oleh Haselkom, Chen, Miller, Fish, Peters, Weiss \& Jones (2010) yang mengevaluasi hubungan antara asma yang tidak terkontrol dan keterbatasan aktivitas. Pasien yang berpartisipasi dalam evaluasi asma dan studi pengobatan asma disurvei mengenai jenis dan tingkat keterbatasan aktivitas dalam 4 kategori yaitu aktivitas di luar rumah, aktivitas fisik, aktivitas sehari-hari, dan pemicu lingkungan. Hasil penelitian terdapat hubungan yang signifikan antara asma yang tidak terkontrol dan pembatasan aktivitas. Dibandingkan dengan penderita asma terkontrol, penderita asma yang tidak terkontrol berisiko tinggi mengalami keterbatasan aktivitas di luar, aktivitas fisik, dan aktivitas sehari-hari. Untuk membantu pasien mencapai kesehatan optimal, manajemen asma harus mencakup penilaian rutin terhadap keterbatasan aktivitas dan perawatan terkoordinasi.

Pada saat penelitian, terdapat 1 responden yang mengalami kekambuhan pada minggu ke empat latihan dikarenakan alergi. Rumah responden tersebut sedang direnovasi, sehingga banyak debu-debu. Klien mengaku memiliki riwayat alergi terhadap debu yang memicu terjadinya kekambuhan asma. Oleh karena klien tidak melakukan latihan teknik pernapasan buteyko sehingga di drop out oleh peneliti. Menurut Crocker et al, (2016) eksaserbasi asma dipicu oleh alergen dalam rumah terutama pada keluarga yang belum mendapatkan pendidikan kesehatan. Lingkungan rumah terkait erat dengan kesehatan penghuninya. Alergen dalam ruangan seperti debu rumah, tungau, kecoa berisiko mengembangkan asma. Kualitas perumahan yang buruk sangat terkait dengan kontrol asma yang buruk.

Faktor lain yang dapat mempengaruhi skor ACT (asthma control test), salah satunya adalah farmakologi, baik bronkodilator maupun kortikosteroid. Namun peneliti tidak melakukan pengukuran terhadap ketepatan responden dalam menggunakan obatobatan inhalasi. Berdasarkan fenomena selama penelitian, ditemukan pasien asma bronkial yang sudah melakukan kontrol berulang tetapi belum mengerti dan masih salah dalam menggunakan obat-obat inhaler. Pada penelitian ini tidak dilakukan pengumpulan data tentang karakteristik dasar pada pasien asma seperti kelompok responden yang menggunaan bronkodilator atau kortikosteroid bahkan keduanya, sehingga tidak terkaji efek obat ini terhadap kontrol asma.

Keunggulan penelitian adalah Latihan teknik pernapasan buteyko yang diberikan tidak membutuhkan pengeluaran biaya. Intervensi ini dapat dilakukan dengan mudah dan mandiri dirumah yang tentunya menguntungkan penderita apabila intervensi tersebut aman dilakukan dan terbukti manfaatnya. Selain itu teknik pernapasan buteyko menggunakan pernapasan hidung, sehingga menghasilkan oksida nitrat. Karena latihan pernapasan buteyko sangat mudah dilakukan dan memberikan efek yang baik, diharapkan para perawat dapat menerapkan atau mengajarkan kepada setiap pasien yang melakukan kontrol asma di Poli Paru. Desain time series memberikan keuntungan tersendiri terhadap penelitian ini. Keuntung tersebut adalah peneliti dapat melihat secara detail perkembangan rerata skor ACT. 


\section{SIMPULAN}

Berdasarkan hasil penelitian dapat dirumuskan simpulan secara umum hasil penelitian ini menemukan ada pengaruh latihan teknik pernapasan buteyko terhadap ACT (asthma control test) dengan rincian :

Skor ACT setelah diberikan teknik pernapasan buteyko lebih tinggi daripada sebelum diberikan teknik pernapasan buteyko. Perbedaan yang signifikan antara skor ACT setelah diberikan teknik pernapasan buteyko dengan skor ACT pada minggu III, minggu II, minggu I, dan pretest $(p=0,00)$. Post hoc analisis menemukan skor post test minggu ke empat signifikan lebih tinggi $(p=0,00)$ daripada posttest minggu III, minggu II, minggu I, dan pretest.

\section{SARAN}

Hasil penelitian menemukan ada pengaruh latihan teknik pernapasan buteyko terhadap kontrol asma bronkial. Diharapkan intervensi ini dijadikan bahan telaah (evidence based) bagi perawat dalam pengelolaan asma dengan menggunakan teknik pernapasan buteyko. Sebelum penelitian dimulai diharapkan responden diberikan edukasi tentang cara penggunaan obat inhaler sehingga kontrol asma dapat tercapai dan juga melakukan tes kepatuhan pasien dalam melakukan latihan pernapasan buteyko dan perlu dilakukanpenelitian dengan waktu yang lebih panjang (2-6 bulan) untuk mencapai kontrol asma yang normal.

Pada penelitian selanjutnya diharapkan untuk melakukan pengumpulan data tentang karakteristik dasar seperti kelompok responden yang mengkonsumsi bronkodilator, kortikosteroid atau kedua obat-obatan ini, sehingga akan terlihat jelas perbedaan pengaruh teknik pernapasan buteyko terhadap kontrol asma. Selain itu, penelitian teknik pernapasan buteyko diberikan pengawas latihan untuk memantau kepatuhan responden dalam melakukan latihan teknik pernapasan buteyko.

\section{DAFTAR PUSTAKA}

American College of Chest Physicians. (2004). Controlling Your Asthma. Patient Education Guide. National Asthma Education and Prevention Program; National Heart, Lung, and Blood Institute; NIH Publication, 97-4053

Barnes, P. J., \& Drazen, J. M. (2009). Pathophysiology of Asthma. Asthma and COPD, 399-423. https://doi.org/10.1016/B978-0-12-374001-4.00033-X

Bateman, E. D., Hurd, S. S., Barnes, P. J., Bousquet, J., Drazen, J. M., FitzGeralde, M., Zar, H. J. (2008). Global Strategy for Asthma Management and Prevention: GINA Executive Summary. European Respiratory Journal, 31(1), 143-178. http://doi.org/10.1183/09031936.00138707

Bedouch, P., Marra, C. A., FitzGerald, J. M., Lynd, L. D., \& Sadatsafavi, M. (2012). Trends in Asthma-Related Direct Medical Costs from 2002 to 2007 in British Columbia, Canada: A Population Based-Cohort Study. PLoS ONE, 7(12). https://doi.org/10.1371/journal.pone.0050949

Black \& Hawks. (2014). Keperawatan Medikal Bedah. Manajemen Klinis untuk Hasil yang Diharapkan. Elsevier: Singapura

Bruton, A., \& Lewith, G. T. (2005). The Buteyko Breathing Technique for Asthma: A Review. Complementary Therapies in Medicine, 13(1), 41-46. https://doi.org/10.1016/j.ctim.2005.01.003

Bruurs, M. L. J., Van Der Giessen, L. J., \& Moed, H. (2013). The Effectiveness of Physiotherapy in Patients with Asthma: A Systematic Review of the Literature. 
Respiratory Medicine, $\quad$ 107(4), 483-494. http://doi.org/10.1016/j.rmed.2012.12.017

Crocker, D. D., Kinyota, S., Dumitru, G. G., Ligon, C. B., Herman, E. J., Ferdinands, J. M., Sipe, T. A. (2016). Effectiveness of Home-Based, Multi-Trigger, Multicomponent Interventions with an Environmental Focus for Reducing Asthma Morbidity. American Journal of Preventive Medicine, 41(2), S5-S32. https://doi.org/10.1016/j.amepre.2011.05.012

Cooper, S., Oborne, J., Newton, S., Harrison, V., Coon, J. T., Lewis, S., \& Tattersfield, A. (2003). T 1999, 674-680

Courtney, R. (2007). Strengths, Weaknesses, and Possibilities of the Buteyko Breathing Method. Biofeedback, 36(2), 59-63

Cowie, R. L., Conley, D. P., Underwood, M. F., \& Reader, P. G. (2008). A Randomised Controlled Trial of the Buteyko Technique as an Adjunct to Conventional Management of Asthma. Respiratory Medicine, 102(5), 726-732. http://doi.org/10.1016/j.rmed.2007.12.012

Dahlan, Z.,Amin Z., \& Soeroto A Y (2012). Kompendium Tatalaksana Penyakit Respirasi \& Kritis Paru. Perhimpunan Respirologi Indonesia. Bandung

Dal Negro, R. W., Micheletto, C., Tosatto, R., Dionisi, M., Turco, P., \& Donner, C. F. (2007). Costs of Asthma in Italy: Results of the SIRIO (Social Impact of Respiratory Integrated Outcomes) Study. Respiratory Medicine, 101(12), 25112519. http://doi.org/10.1016/j.rmed.2007.07.011

Ducharme, F., \& Chauhan, B. (2014). Anti-Leukotriene Agents Compared to Inhaled Corticosteroids in the Management of Recurrent and / or Chronic Asthma in Adults and Children (Review). Cochrane Database of Systematic Reviews, (4). http://doi.org/10.1002/14651858.CD002314.pub3.Anti-leukotriene

Eder, W., Ege, M. J., \& von Mutius, E. (2006). The Asthma Epidemic. N Engl J Med, (355), 2226-2235. http://doi.org/10.1056/NEJMra054308

Fm, D., M, N. C., Greenstone, I., \& Tj, L. (2010). Addition of Long-Acting Beta2Agonists to Inhaled Steroids Versus Higher Dose Inhaled Steroids in Adults and Children with Persistent Asthma (Review) Addition of Long-Acting Beta2Agonists to Inhaled Steroids Versus Higher Dose Inhaled Steroids in Adult. The Cochrane Library, (4), 2-4. http://doi.org/10.1002/14651858.CD005533.pub2.Copyright

Global Initiativef or Asthma (GINA) (2006). Global Strategy for Asthma Management and Prevention

Global Asthma Network. (2014). The Global Asthma Report 2014 (Vol. 5). http://doi.org/ISBN: 978-0-473-29125-9978-0-473-29126-6 (ELECTRONIC)

Haselkom, Chen, Miller, Fish, Peters, Weiss, \& Jones (2010). Asthma Control and Activity Limitations: Insights from the Real-World Evaluation of Asthma Control and Treatment (REACT) Study. doi: http://dx.doi.org/10.1016/j.anai.2010.04.006

Hassan, Z. M., Riad, N. M., \& Ahmed, F. H. (2012). Effect of Buteyko Breathing Technique on Patients with Bronchial Asthma. Egyptian Journal of Chest Diseases and Tuberculosis, 61(4), 235-241. http://doi.org/10.1016/j.ejcdt.2012.08.006

Higashi, A., Zhu, S., Stafford, R. S., \& Alexander, G. C. (2011). National Trends in Ambulatory Asthma Treatment, $1997 \quad-\quad 2009$, 1465-1471. https://doi.org/10.1007/s11606-011-1796-4 
Hsu, King, Kuo, \& Chiang (2004). Age of Onset and the Characteristics of Asthma. Europe PMC. doi: 10.1111/j.1440-1843.2004.00572.x. PMID:1536301

Kim B K, Kwon J W, Kim M H, Song W J, Kim T W, Kwon J W. (2010). Allelic Variants of CD86 and CD40L Genes Interact in the Development of Atopic Asthma. American Journal of Respiratory and Critical Care Medicine. 181: A1319

Kullowatz, A., Kanniess, F., Dahme, B., Magnussen, H., \& Ritz, T. (2007). Association of Depression and Anxiety with Health Care Use and Quality of Life in Asthma Patients. Respiratory Medicine, 101(3), 638-644. http://doi.org/10.1016/j.rmed.2006.06.002

Li, J. T., Oppenheimer, J., Bernstein, I. L., Nicklas, R. A., Khan, D. A., BlessingMoore, J., ... Wallace, D. V. (2005). Attaining Optimal Asthma Control: A Practice Parameter. Journal of Allergy and Clinical Immunology, 116(5), 1-9. http://doi.org/10.1016/j.jaci.2005.08.017

Maslan, J., \& Mims, J. (2014). What is Asthma. Otolaryngologic Clinics of North America, 47(1), 13-22

Masoli, M., Fabian, D., Holt, S., \& Beasley, R. (2004). The Global Burden of Asthma: Executive Summary of the GINA Dissemination Committee Report. Allergy: European Journal of Allergy and Clinical Immunology, 59(5), 469-478. http://doi.org/10.1111/j.1398-9995.2004.00526.x

Mchugh, P., Aitcheson, F., Duncan, B., \& Houghton, F. (2003). The New Zealand intervention, 116(1187), 1-7

Nhs American Academy Of Allergy Asthma And Immunology. (2014). Introduction to Asthma, (June). Retrieved from http://www.nhs.uk/conditions/asthma/Pages/Introduction.aspx

Penelitian, B., \& Pengembangan, D. A. N. (2013). Riset Kesehatan Dasar. http://doi.org/10.1007/s13398-014-0173-7.2

Prem, V., Sahoo, R. C., \& Adhikari, P. (2013). Comparison of the Effects of Buteyko and Pranayama Breathing Techniques on Quality of Life in Patients with Asthma - a Randomized Controlled Trial. Clin Rehabil, 27(2), 133-141. http://doi.org/10.1177/0269215512450521

Purnomo. 2008. Faktor Resiko Yang Berpengaruh terhadap Kejadian Asma Bronkial pada Anak. Universitas Diponegoro: Semarang

Rakhimov, A. (2013). Advanced Buteyko Breathing Exercises

Solomen, S., \& Aaron, P. (2016). Breathing Techniques-A Review - 25 Different Types Breathing Techniques- A Review, 1(October 2015)

Thomas, S. (2004). Buteyko: A Useful Tool in the Management of Asthma? International Journal of Therapy and Rehabilitation, 11(10), 476-479. http://doi.org/10.12968/ijtr.2004.11.10.17190

To, T., Stanojevic, S., Feldman, R., Moineddin, R., Atenafu, E. G., Guan, J., \& Gershon, A. S. (2013). Is Asthma a Vanishing Disease? A Study to Forecast the Burden of Asthma in 2022. BMC Public Health, 13(1), 254. http://doi.org/10.1186/1471-2458-13-254

Tobergte, D. R., \& Curtis, S. (2013). Intergovernmental Panel on Climate Change. Journal of Chemical Information and Modeling, 53(9), 16891699. https://doi.org/10.1017/CBO9781107415324.004

Villareal, G. M. C., Villazor, B. P. U., Villegas, A. M., Visaya, S. N., Vista, M. E., Tan, C. B., \& G, C. E. (2014). Health and Medicine Effect of Buteyko Method on 
Asthma Control and Quality of Life of Filipino Adults with Bronchial Asthma, 2(1), 44-60

Williams, S. G., Schmidt, D. K., Redd, S. C., \& Storms, W. (2003). Key Clinical Activities for Quality Asthma Care. Recommendations of the National Asthma Education and Prevention Program. MMWR. Recommendations and Reports: Morbidity and Mortality Weekly Report. Recommendations and Reports / Centers for Disease Control, 52(RR-6), 1-8. Retrieved from http://www.ncbi.nlm.nih.gov/pubmed/12696781

Weiner, R., Magadle, J., Waizman, M., Weiner, M., Rabner, D., Zamir. (1998). Characteristics of asthma in the elderly. Europe Respiratory Journal,12: 564-5 